\title{
IMPACT OF ATMOSPHERIC PRECIPITATION ON THE VARIABILITY OF WASTEWATER DISCHARGE FROM A SELECTED SEWAGE SYSTEM IN JAWORZNO
}

\author{
Krzysztof Chmielowski ${ }^{\bowtie}$ \\ Faculty of Environmental Engineering and Land Surveying, University of Agriculture in Krakow, al. Mickiewicza 24/28, \\ 30-059 Kraków
}

\begin{abstract}
Aim of the study

The present paper analyses the influence of atmospheric precipitation on the variability of wastewater discharge from a selected sewerage system located in southern Poland. The research period covered the years 2011-2016. The daily outflows of wastewater from the sewerage system were adopted.
\end{abstract}

\begin{abstract}
Material and methods
Precipitation data were obtained from a station located $7 \mathrm{~km}$ away from the tested facility (the nearest rainfall measurement station from the tested object) and based on this data, the mean daily precipitation values were determined for the examined period. Subsequently, the research period was divided, according to the amount of precipitation, into 7 basic groups. It was determined whether the mean values of wastewater discharge from the sewerage system in particular groups of rainfall intensity significantly differed from each other. The analysis was carried out using a one-way analysis of variance (ANOVA). The groups of rainfall intensity constituted the factor determining the value of wastewater outflow from the sewage agglomeration.
\end{abstract}

\section{Results and conclusions}

Based on the results of the research we conducted, actions were proposed aimed at increasing the control of accidental water outflow to the sewerage system. Based on that, operations have been determined, minimizing the inflow of accidental rainwaters to particularly sensitive sections of the sewerage system. Training should be provided for municipalities of the agglomeration, regarding the management of rainwater, so as to stop the inflow as far as possible, in the locations where it may arise.

Keywords: precipitation, sewage, wastewater treatment plant

\section{INTRODUCTION}

Discharging wastewater from sewage agglomerations is an important and current problem. In this respect, various legal acts are in force, specifying the conditions for wastewater disposal by sewage systems and their treatment in collective sewage treatment plants. In Poland, one of the most important is the Sewage
Directive (Directive, 1991) on the basis of which lower-ranking documents have been suitably adjusted (Act, 2001). The aforementioned Act removes the following from the current definition of wastewater: rainwater and snowmelt in open or closed sewage systems originating from contaminated surfaces with solid surface, in particular from cities, ports, airports, from industrial, commercial, service and storage areas

凶e-mail: k.chmielowski@ur.krakow.pl 
as well as transportation bases, roads and parking lots, which ultimately results in the so-called rainwater no longer constituting wastewater in the meaning of the law. The exception to the above-mentioned changes is the situation in which rainwater and snowmelt are discharged by a combined sewage system, i.e. when the rainwater mixes with municipal wastewater, then it will be included in the notion of municipal sewage. Implementing legislation for the Act includes the Regulation (2014a) in the field of quality of wastewater that can be discharged to water and soil, and the Regulation (2014b) on the method of determining the area and boundaries of an agglomeration. Another document of high significance to water and sewage management is the National Municipal Wastewater Treatment Program (2003), which since had several updates and amendments (Miernik and Młyński, 2014a; Miernik and Młyński, 2014b; Bugajski et al., 2017; Chmielowski et al., 2016). The abovementioned document includes much information about agglomerations equipped with sewage systems completed with collective sewage treatment plants. One of the elements it presents is the projected capacity and the actual capacity of sewage treatment plants. This is a very important issue from the point of view of the exploitation of a potential wastewater treatment plant (Młyński and Chmielowski, 2017; Kaczor, 2011). The correct dimensioning of the sewerage network depends mainly on the correct determination of human water needs (Bergel and Pawełek, 2005; Chotkowski and Lis, 2006). Overloading the plant, or its insufficient loading, may adversely affect the wastewater treatment processes, and it may lead to deterioration in the quality of wastewater discharged to the receiver. Increased amount of wastewater inflowing into the sewage treatment plant may also be caused by factors such as mechanical damage to sewage pipes or their leaks, causing infiltration water inflow (Kaczor et al., 2017; Wąsik et al., 2017; Kaczor and Przebinda, 2009). In extreme cases, the foreign (external) water incoming into the sewerage network may even cause a five-fold increase in the mean daily outflow of wastewater to the treatment plant (Kaczor and Pawełek, 1999). The correct operation of a sewage treatment plant is primarily dependent on its hydraulic load.

The aim of the present article was to determine the impact of atmospheric precipitation on the variability of wastewater outflow from a selected sewage agglomeration system in southern Poland (Jaworzno). The research period covered the years 2011-2016. Daily outflows of wastewater from the sewage agglomeration were adopted for the analysis. The research period has been divided according to the groups of precipitation intensity. The mean wastewater outflow to the treatment plant was determined for each of the precipitation intensity groups. The impact of atmospheric precipitation on the outflow of wastewater from the facility has been determined. The basic descriptive statistics regarding wastewater outflow from the sewage agglomeration were determined: mean $\left(Q_{d \mathrm{~s} s}\right)$, median $\left(M_{o}\right)$, minimum $\left(Q_{d \min }\right)$, maximum $\left(Q_{d \max }\right)$, standard deviation $(\sigma)$, coefficient of variation $\left(\mathrm{V}_{z m}\right)$, and range $\left(R_{o}\right)$. The above descriptive statistics were determined for particular years separately, and for the studied period as a whole.

\section{DESCRIPTION OF THE STUDIED FACILITY}

The research object was the Jaworzno sewage agglomeration, located in southern Poland. It is an agglomeration with one collective wastewater treatment plant. The number of actual inhabitants in the agglomeration is 96,183 people, whereas the number of inhabitants using the sewage system is 83,854 people, and the number of inhabitants served by the slurry tank is 9102 people. The length of the sewerage network in the agglomeration is $340.6 \mathrm{~km}$, of which the combined sewerage system covers $137.9 \mathrm{~km}$ (that amounts to $40.6 \%$ ), and the sanitary sewage system covers $202.1 \mathrm{~km}$ (which amounts to $59.4 \%$ ). It is a network that is draining wastewater in a gravitational system. There exists a storm overflow, which is a part of a combined sewerage system. Wastewater from the agglomeration flows into a collective sewage treatment plant with an RLM of 102 973. The main installation of the treatment plant is a biological flow reactor based on the activated sludge process. The treated wastewater can be discharged to the waters in the following quantity: $Q_{\text {srd }}=25000 \mathrm{~m}^{3} \cdot \mathrm{d}^{-1}$.

\section{RESEARCH METHODOLOGY}

The work specifies the variability of wastewater outflow from sewage agglomeration in southern Poland. The basic descriptive statistics regarding sewage out- 
flow from the sewage agglomeration were determined: mean value $\left(Q_{d \mathrm{sir}}\right)$, median $\left(M_{o}\right)$, minimum $\left(Q_{d \min }\right)$, maximum $\left(Q_{d \max }\right)$, standard deviation $(\sigma)$, coefficient of variation $\left(V_{z m}\right)$, and range $\left(R_{o}\right)$. The histogram of wastewater inflows to the sewage treatment plant has been presented for given observation intervals. The daily outflows of wastewater from the examined sewage agglomeration in 2011-2016 were compared against the limit value from the permit required by the Water Law Act and the mean value. The mean daily values of wastewater flows have been summarized for particular months of the year, for the period 2011-2016. Precipitation data was obtained from the station located $7 \mathrm{~km}$ away from the facility (the nearest precipitation station from the tested object), and based on that the mean values of the daily atmospheric precipitation for the examined period were determined. Subsequently, the studied period was subdivided according to the amount of precipitation, into 7 basic groups:

- "O1" group - days without rainfall and days with rainfall up to $1 \mathrm{~mm} \cdot \mathrm{d}^{-1}$,

- "O2" group - days with rainfall over $1.1 \mathrm{~mm} \cdot \mathrm{d}^{-1}$ and below $5 \mathrm{~mm} \cdot \mathrm{d}^{-1}$,

- "O3" group - from $5.1 \mathrm{~mm} \cdot \mathrm{d}^{-1}$ to $10 \mathrm{~mm} \cdot \mathrm{d}^{-1}$,

- "O4" group - from $10.1 \mathrm{~mm} \cdot \mathrm{d}^{-1}$ to $15 \mathrm{~mm} \cdot \mathrm{d}^{-1}$,

- "O5" group - from $15.1 \mathrm{~mm} \cdot \mathrm{d}^{-1}$ to $20 \mathrm{~mm} \cdot \mathrm{d}^{-1}$,

- "O6" group - from $20.1 \mathrm{~mm} \cdot \mathrm{d}^{-1}$ to $25 \mathrm{~mm} \cdot \mathrm{d}^{-1}$,

- and "O7" group -above $25 \mathrm{~mm} \cdot \mathrm{d}^{-1}$.

The precipitation intensity group "O1" contains days in which the atmospheric precipitation remained in the range from 0 to $1 \mathrm{~mm} \cdot \mathrm{d}^{-1}$ (it was assumed that the rainfall below $1 \mathrm{~mm} \cdot \mathrm{d}^{-1}$ does not generate outflow to the sewage system).

In addition, four groups were introduced, taking into account the period without precipitation:

- "S1" group - number of days without rainfall: from 1 to 9 days,

- "S2" group - from 10 to 19 days without rainfall,

- "S3" group - from 20 to 29 days without rainfall,

- "S4" group - over 30 days without rainfall.

On that basis, the dependence of wastewater outflow from the examined sewage agglomeration on the intensity of rainfall has been determined.

Next, it was determined whether the mean values of wastewater outflow from sewage agglomeration in particular groups of precipitation intensity significantly differ from each other. This analysis was carried out using a one-way analysis of variance (ANOVA). Daily values of wastewater outflows from sewage agglomeration were adopted as the dependent variable. The groups of precipitation intensity constituted the factor determining the value of wastewater outflow from the sewage agglomeration.

Formally, for the test of differences between multiple mean values to be applied, it is required that there exist significant differences between the variances in each group. In empirical studies, wherever ANOVA analysis was used, Levene's test did not reject the null hypothesis about the lack of significant differences between the variances.

\section{ANALYSIS AND DISCUSSION OF RESEARCH RESULTS}

First, basic descriptive statistics of wastewater outflow from sewage agglomeration are presented in Table 1.

On the basis of the data contained in Table 1, one can notice a large variation in the value of wastewater outflow from sewage agglomeration throughout the entire studied period. Similarly, large variability of outflow was obtained by the authors (Kaczor, 2011; Młyński and Chmielowski, 2017) who investigated wastewater outflow from other sewage systems. Mean wastewater outflow over the entire 2011-2016 period amounted to $13688.5 \mathrm{~m}^{3} \cdot \mathrm{d}^{-1}$ and accounted for $54.8 \%$ of the planned flow $\left(Q_{\text {srd }}=25,000 \mathrm{~m}^{3} \cdot \mathrm{d}^{-1}\right)$. Therefore, the sewage treatment plant can work on a much higher hydraulic load than the current one, and thus it would be feasible to expand the existing sewage system and to connect additional new users thereto. Insufficient hydraulic load in a wastewater treatment plant is a frequent occurrence, as demonstrated by the work by the authors (Bugajski et al., 2016a; Bugajski and Ślizowski, 2006). Broken down for each year, the highest mean daily flow of wastewater was for 2016 $\left(Q_{d \mathrm{~s} \mathrm{r}}=15702.6 \mathrm{~m}^{3} \cdot \mathrm{d}^{-1}\right)$ and the maximum daily flow amounted to $\left(Q_{d \max }=40630.0 \mathrm{~m}^{3} \cdot \mathrm{d}^{-1}\right)$. Intensive atmospheric precipitation was the reason for such high values. In turn, extremely low values of wastewater outflow were observed at the level of $5302.0 \mathrm{~m}^{3} \cdot \mathrm{d}^{-1}$, which occurred in the rainless period. The high value of the outflow of wastewater to the tested facility is confirmed by the high value of the range (for the examined multi-year period $\left.R=35328.0 \mathrm{~m}^{3} \cdot \mathrm{d}^{-1}\right)$. 
Chmielowski, K. (2019). Impact of atmospheric precipitation on the variability of wastewater discharge from a selected sewage system in Jaworzno. Acta Sci. Pol., Formatio Circumiectus, 18 (2), 39-49. DOI: http://dx.doi.org/10.15576/ASP.FC/2019.18.2.39

Table 1. Basic descriptive statistics of wastewater outflow from the sewage agglomeration system

\begin{tabular}{lccccccccc}
\hline \multicolumn{1}{c}{ Parameter of wastewater outflow } & \multicolumn{7}{c}{ Value of the parameter } \\
\hline \multicolumn{1}{c}{ Name } & Symbol & Unit & 2011 & 2012 & 2013 & 2014 & 2015 & 2016 & $2011-2016$ \\
\hline Maximum outflow & $Q_{d \max }$ & $\mathrm{m}^{3} \cdot \mathrm{d}^{-1}$ & 26380 & 30750 & 31100 & 36510 & 31807 & 40630 & 40630 \\
\hline Mean outflow & $Q_{d \mathrm{~s} \mathrm{r}}$ & $\mathrm{m}^{3} \cdot \mathrm{d}^{-1}$ & 12999 & 11837 & 14196 & 12955 & 14441 & 15703 & 13688 \\
\hline Minimum outflow & $Q_{d \min }$ & $\mathrm{m}^{3} \cdot \mathrm{d}^{-1}$ & 7080 & 5442 & 5910 & 5740 & 5302 & 6920 & 5302 \\
\hline Median & $M_{o}$ & $\mathrm{~m}^{3} \cdot \mathrm{d}^{-1}$ & 12070 & 10595 & 13310 & 12220 & 13600 & 14910 & 12829 \\
\hline Standard deviation & $s$ & $\mathrm{~m}^{3} \cdot \mathrm{d}^{-1}$ & 3453 & 3410 & 3970 & 3982 & 3706 & 4533 & 4053 \\
\hline Coefficient of variation & $V_{s}$ & - & 0.27 & 0.29 & 0.28 & 0.31 & 0.26 & 0.29 & 0.30 \\
\hline Range & $R$ & $\mathrm{~m}^{3} \cdot \mathrm{d}^{-1}$ & 19300 & 25308 & 25190 & 30770 & 26505 & 33710 & 35328 \\
\hline Number of samples & $N$ & $\mathrm{pcs}$. & 365 & 366 & 365 & 365 & 365 & 366 & 2192 \\
\hline
\end{tabular}

In addition, mean daily wastewater flow for the entire period (the horizontal line) and design flow are marked. When analysing the data from Figure 1, a significant unevenness of wastewater outflow to the treatment plant can be observed. Significant differences in the value of wastewater outflow to the treatment plant could have been influenced by rainwater. The highest value of wastewater outflow to the treatment plant $\left(40630 \mathrm{~m}^{3} \cdot \mathrm{d}^{-1}\right)$ was observed at an atmospheric precipitation of $14.7 \mathrm{~mm} \cdot \mathrm{d}^{-1}$.

The dotted line marks the boundaries between rainless weather and the period with atmospheric precipitation (see: Fig. 2). The higher the number of the "O" precipitation group, the higher the intensity of rainfall (see: research methodology) and the higher the number of the "S" group, the longer the period without precipitation.

The outflow of wastewater from the examined sewage agglomeration system should be considered equal to the inflow of wastewater to the collective treatment plant. Figure 2 shows a clear increase in wastewater outflow to the sewage treatment plant with the increase of the precipitation intensity group.

For the group "O1" (days without rainfall), the mean wastewater outflow from the sewage agglomeration amounted to $12,759 \mathrm{~m}^{3} \cdot \mathrm{d}^{-1}$, while for the last group "O7" (with rain intensity of $25 \mathrm{~mm} \cdot \mathrm{d}^{-1}$ ) the mean wastewater outflow from sewage agglomeration amounted to $24767 \mathrm{~m}^{3} \cdot \mathrm{d}^{-1}$. There was an increase in the volume of wastewater flowing out of the sewage agglomeration by $12597 \mathrm{~m}^{3} \cdot \mathrm{d}^{-1}$, which is an increase of $103.5 \%$ in relation to the outflow of wastewater recorded for the "O1" group. The number of days without rainfall in a multi-year period (groups "O1" + "S1" + "S2" + "S3" + "S4") amounted to $1536 \mathrm{~d}$, which accounted for over $70.0 \%$ of all days in the examined period. Even for precipitation up to $5 \mathrm{~mm} \cdot \mathrm{d}^{-1}$ (group "O2"), the mean wastewater outflow from the sewage agglomeration was increased by $2532 \mathrm{~m}^{3} \cdot \mathrm{d}^{-1}$ in relation to the period without rainfall (group "O1"), which corresponds to an increase of $19.8 \%$. For the remaining precipitation groups, a clear increase in wastewater outflow to the sewage treatment plant was observed along with an increase in the rainfall intensity group. Taking into account the groups from "S1" to "S4", a clear decrease in the mean wastewater outflow to the tested treatment plant can be observed. It turns out that the longer the rainless weather lasted, the smaller the inflow of wastewater to the treatment plant that was recorded. For example, for the group "S1" (rainless period lasting fall from 1 to 9 days), the mean wastewater outflow from the sewage agglomeration amounted to $12,083 \mathrm{~m}^{3} \cdot \mathrm{d}^{-1}$, which corresponds to a decrease by $676 \mathrm{~m}^{3} \cdot \mathrm{d}^{-1}$ (constituting $5.3 \%$ in relation to group "O1"). Whereas for the last group "S4", with the longest dry period, the outflow of wastewater from the sewage agglomeration at the level of $9808 \mathrm{~m}^{3} \cdot \mathrm{d}^{-1}$ was determined. This inflow is $2951 \mathrm{~m}^{3} \cdot \mathrm{d}^{-1}$ smaller than that recorded for the group "O1", which corresponds to a decrease by $23.1 \%$. The decrease in wastewater out- 


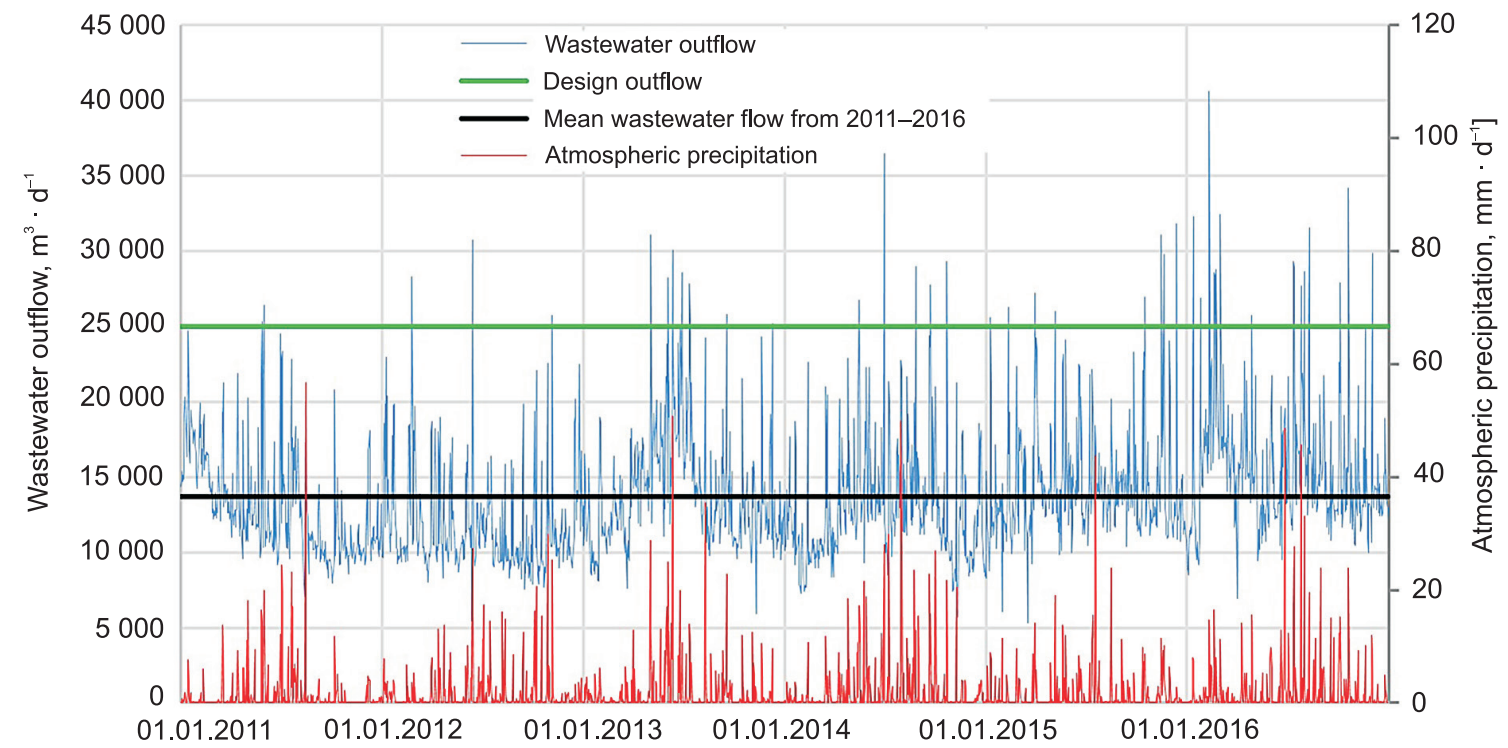

Fig. 1. Daily wastewater outflow from the sewage agglomeration in 2011-2016

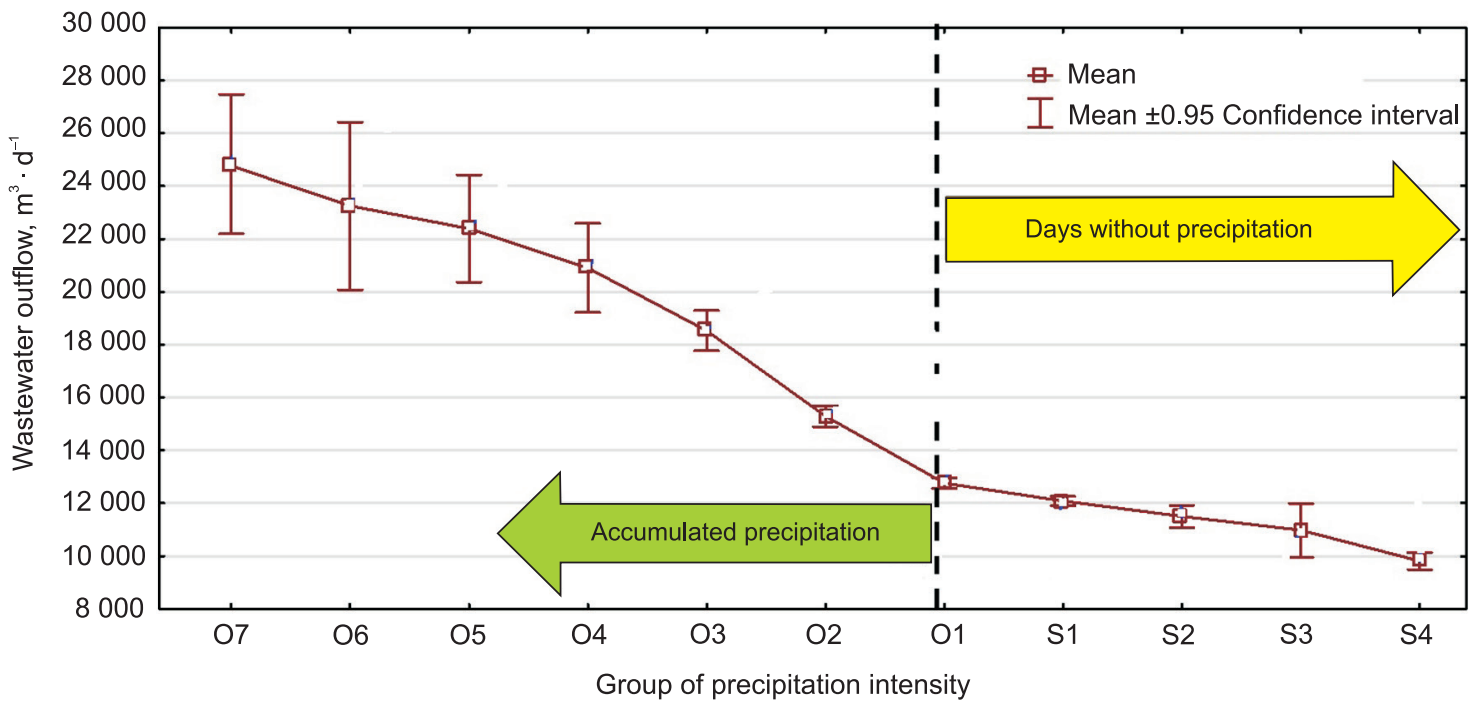

Fig. 2. Mean values of wastewater outflow for particular groups of atmospheric precipitation in 2011-2016

flow to treatment plants in various groups of rainless weather may point to a decreasing amount of infiltration water entering the sewage system through leaks. The period of rainless weather lasting several dozen days may cause the groundwater table to lower, and this in turn may affect the amount of infiltration water entering the sewage system. The presented division of days due to the duration of rainless weather can be helpful in determining the amount of infiltration water entering the sewage system. In the analysed example, this can be determined at an average level of at least $23.1 \%$ of the total volume of sanitary sewage.

Due to the fact that the sewage system in the sewage agglomeration consists of $40.6 \%$ of the combined 
sewage system, it can be expected that this should cause an increase in the amount of wastewater during rainfall. The intensity of inflow of rainwater to the sewage system may also be influenced by illegal connections of gutters that collect water from the roofs of the properties (this concerns sanitary sewage constituting $60 \%$ of the total sewage system). In the sewage agglomeration there are over $340.0 \mathrm{~km}$ of sewage network, of which the combined sewerage system occupies $137.9 \mathrm{~km}$ (corresponding to $40.6 \%$ ), and the sanitary sewage system covers $202.1 \mathrm{~km}$ (corresponding to $59.4 \%$ ). According to Kaczor et al. (2017) foreign (external) water gets through the sewer system leaks or openings in manhole hatches, or it is illegally discharged from the roof gutters and yard drains, connected to the sanitary sewage system. It is necessary to provide education and training in municipalities in the field of rainwater management in a given property, which will contribute to the retention of these waters in the place of their formation, and will stop the illegal connection of roof gutters to the sanitary sewage system. As the greater amount of sewage contributes to the increase in operating costs of the treatment plant, the residents should consider alternative ways of retaining rainwater on their property and then using it for their own needs. The amount of wastewater incoming to the sewage treatment plant may also be affected by infiltration waters, however, confirmation of their impact would require a detailed analysis of wastewater outflow to the treatment plant at particular hours of the day. On this basis, it would be possible to determine the amount of wastewater flowing into the treatment plant at night and then determine the percentage of outflow of infiltration waters to the sewage system.

The test probability value below 0.05 indicates a significant difference between the particular pairs of mean values of wastewater outflow to the treatment plant in individual intensity groups of atmospheric precipitation. This means that the intensity of atmospheric precipitation is a decisive factor in the significance of the wastewater outflow to the treatment plant. This does not apply to the relationship between the mean value of wastewater outflow to the treatment plant for rainfall intensity groups: "O7" and "O6"; "O7" and "O5"; "O5" and "O6"; "O6" and "O4"; as well as "O5" and "O4". Also for groups without rainfall from "S1" to "S4", the differences between the mean wastewater inflows to the treatment plant in these precipitation groups were not statistically significant.

Having analysed the data presented in Figure 3, we observe that in rainfall groups of higher intensity of atmospheric precipitation, higher values of the mean temperature of wastewater flowing into the treatment plant were recorded. For the neutral group "O1", the mean temperature of wastewater flowing into the

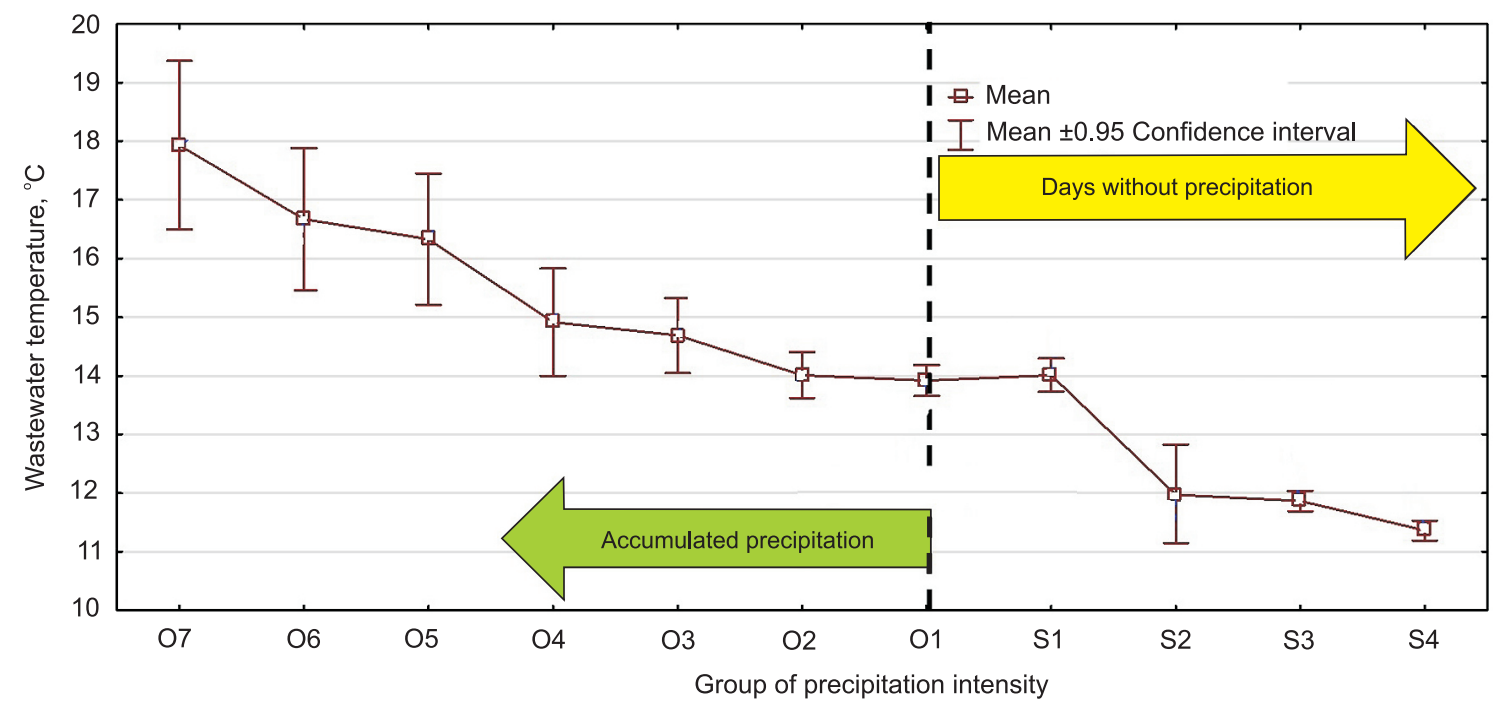

Fig. 3. Mean values of wastewater temperature for particular groups of atmospheric precipitation in 2011-2016 
Chmielowski, K. (2019). Impact of atmospheric precipitation on the variability of wastewater discharge from a selected sewage system in Jaworzno. Acta Sci. Pol., Formatio Circumiectus, 18 (2), 39-49. DOI: http://dx.doi.org/10.15576/ASP.FC/2019.18.2.39

Table 2. Values of test probability - Tukey's HSD test between possible pairs of mean wastewater outflows to the sewage treatment plant for particular groups of atmospheric precipitation

\begin{tabular}{|c|c|c|c|c|c|c|c|c|c|c|c|}
\hline \multirow{2}{*}{$\begin{array}{l}\text { Atmospheric } \\
\text { precipitation } \\
\text { group }\end{array}$} & \multicolumn{11}{|c|}{$\begin{array}{l}\text { Tukey's HSD test probability for statistical significance of differences between possible pairs of mean } \\
\text { wastewater outflows to the sewage treatment plant, for particular groups of atmospheric precipitation }\end{array}$} \\
\hline & $\{07\}$ & $\{06\}$ & $\{\mathrm{O} 5\}$ & $\{\mathrm{O} 4\}$ & $\{\mathrm{O} 3\}$ & $\{\mathrm{O} 2\}$ & $\{\mathrm{O} 1\}$ & $\{\mathrm{S} 1\}$ & $\{\mathrm{S} 2\}$ & $\{\mathrm{S} 3\}$ & $\{\mathrm{S} 4\}$ \\
\hline \multicolumn{12}{|l|}{07} \\
\hline$\{06\}$ & 0.977 & & & & & & & & & & \\
\hline$\{\mathrm{O} 5\}$ & 0.477 & 1.000 & & & & & & & & & \\
\hline$\{\mathrm{O} 4\}$ & 0.016 & 0.735 & 0.860 & & & & & & & & \\
\hline$\{\mathrm{O} 3\}$ & 0.000 & 0.005 & 0.000 & 0.002 & & & & & & & \\
\hline$\{\mathrm{O} 2\}$ & 0.000 & 0.000 & 0.000 & 0.000 & 0.000 & & & & & & \\
\hline$\{\mathrm{O} 1\}$ & 0.000 & 0.000 & 0.000 & 0.000 & 0.000 & 0.000 & & & & & \\
\hline$\{\mathrm{S} 1\}$ & 0.000 & 0.000 & 0.000 & 0.000 & 0.000 & 0.000 & 0.001 & & & & \\
\hline$\{\mathrm{S} 2\}$ & 0.000 & 0.000 & 0.000 & 0.000 & 0.000 & 0.000 & 0.402 & 0.995 & & & \\
\hline$\{\mathrm{S} 3\}$ & 0.000 & 0.000 & 0.000 & 0.000 & 0.000 & 0.026 & 0.944 & 0.999 & 1.000 & & \\
\hline$\{\mathrm{S} 4\}$ & 0.000 & 0.000 & 0.000 & 0.000 & 0.000 & 0.017 & 0.709 & 0.929 & 0.989 & 1.000 & \\
\hline
\end{tabular}

Values of test probability below 0.05 are marked in red.

treatment plant was $13.9^{\circ} \mathrm{C}$. At the highest intensity of atmospheric precipitation, the mean temperature of wastewater reaching the sewage treatment plant was $17.9^{\circ} \mathrm{C}$, which means that it was $4^{\circ} \mathrm{C}$ higher compared to the group "O1" - without rainfall. The temperature of wastewater that is higher by $4^{\circ} \mathrm{C}$ means much better conditions for the biological treatment of sewage and the development of microorganisms. In the case of persistent rainless weather (groups from "S1" to "S2") a decrease in the mean temperature of wastewater entering the treatment plant was observed. For example, the mean temperature of wastewater inflowing into the treatment plant for the "S4" group was $11.4^{\circ} \mathrm{C}$, which was $2.5^{\circ} \mathrm{C}$ lower compared to the "O1" group. Such correlations result from the fact that groups without rainfall, especially those with a long dry season, fell during the winter period when the wastewater temperature was lower. High temperatures of wastewater flowing into the treatment plant were recorded in the period of the highest precipitation.

When analysing the data presented in Figure 4, it can be concluded that the mean values of wastewater outflow to the treatment plant differed depending on the temperature group. The reference point will be the " $\mathrm{T} 6$ " group, for which the air temperatures ranged from 0.0 to $5.0^{\circ} \mathrm{C}$. There were snow thaws in this group, which could have contributed to the increased amount of wastewater in the sewage system. For the "T6" group, the average value of wastewater outflow to the treatment plant was recorded at $14340 \mathrm{~m}^{3} \cdot \mathrm{d}^{-1}$. This value is definitely higher than in the case of the neighbouring group "T7" (air temperature range from -0.1 to $-5.0^{\circ} \mathrm{C}$ ), for which the mean inflow of wastewater to the treatment plant was determined at $12.174 \mathrm{~m}^{3} \cdot \mathrm{d}^{-1}$. The difference of mean sewage inflows in these two groups amounts to $2166 \mathrm{~m}^{3} \cdot \mathrm{d}^{-1}$. The reason for this is the fact that in the "T6" group melt water from snow thaw occurred (air temperature from 0.0 to $+4.9^{\circ} \mathrm{C}$ ). With the lowering of air temperatures (groups "T8" and "T9"), a further reduction of the mean outflow of wastewater into the sewage treatment plant is observed: respectively, for the "T8" group by $3240 \mathrm{~m}^{3} \cdot \mathrm{d}^{-1}$ and for the "T9" group by $4,200 \mathrm{~m}^{3} \cdot \mathrm{d}^{-1}$. In groups from "T1" to "T5", the mean inflows of wastewater to the treatment plant remained at a similar level.

Having analysed the data presented in Figure 5, we notice a clear correlation between air temperature and wastewater temperature. Air temperatures from "T7" to "T9" comprise days when the air temperature was 


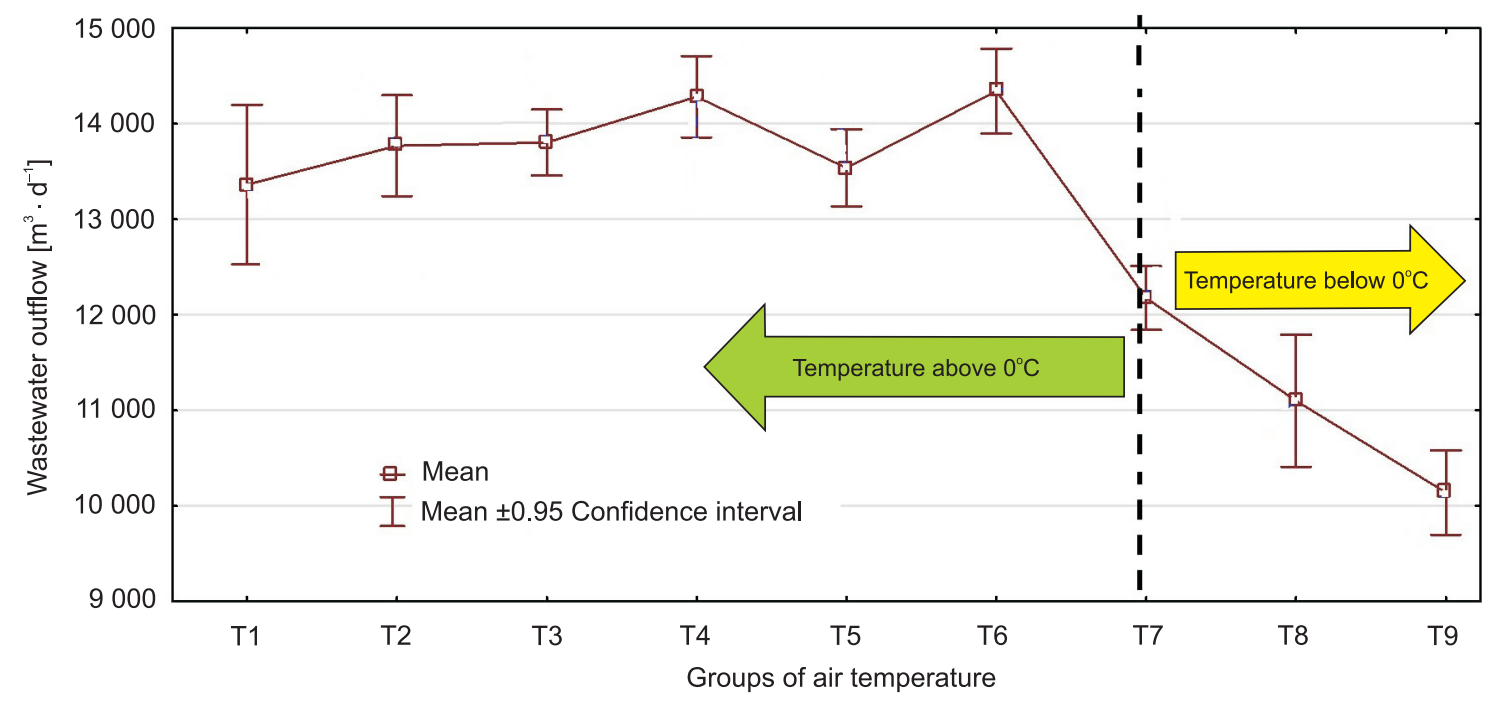

Fig. 4. Mean values of wastewater outflow for particular groups of air temperature in 2011-2016

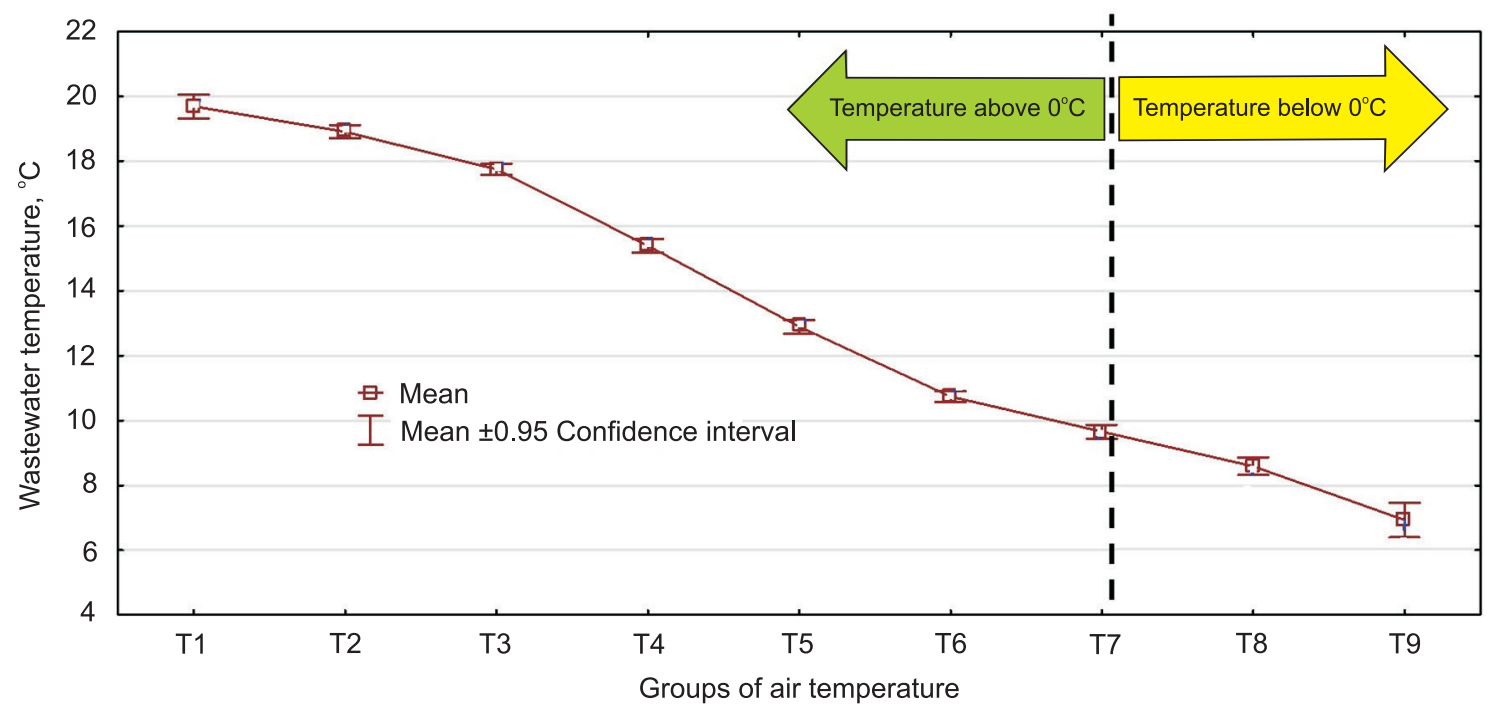

Fig. 5. Mean values of wastewater temperature for particular groups of air temperature in 2011-2016

below $0^{\circ} \mathrm{C}$. For the "T7" group, the mean temperature of wastewater flowing into the sewage treatment plant was $9.7^{\circ} \mathrm{C}$. As the air temperature rises, a clear increase in the temperature of wastewater is observed.

Based on the data presented in Figure 6, we can notice a significantly higher inflow of wastewater in the summer months, especially from May through July. The highest value of wastewater outflow was ob- served in June, amounting to $13.395 \mathrm{~m}^{3} \cdot \mathrm{d}^{-1}$. The lowest value was recorded in the autumn-winter months (from October through January). These results are reflected in the amount of atmospheric precipitation, which was the highest in these months. The highest rainfall (mean daily precipitation) was recorded in June $\left(4.62 \mathrm{~mm} \cdot \mathrm{d}^{-1}\right)$ and the lowest was recorded in February $\left(1.20 \mathrm{~mm} \cdot \mathrm{d}^{-1}\right)$. As in previous cases, the 


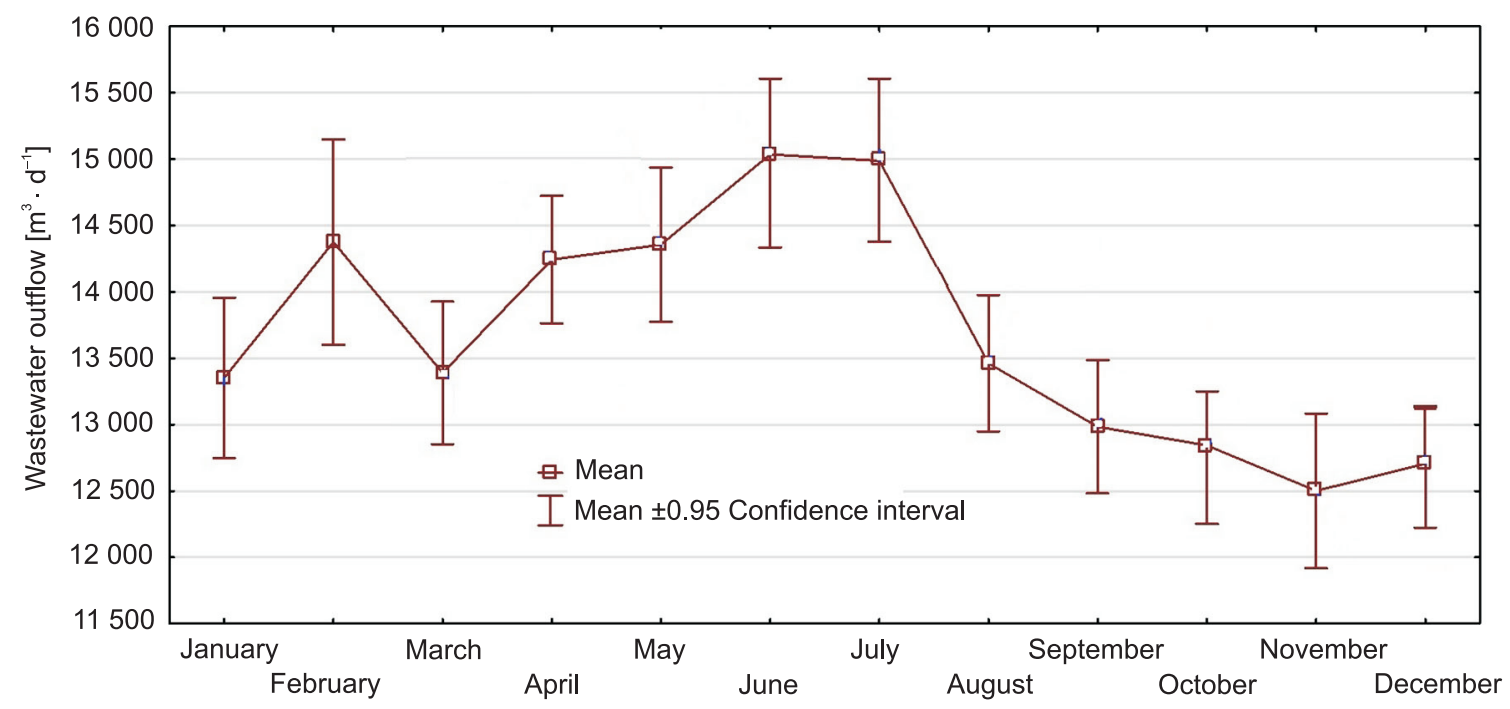

Fig. 6. Mean values of wastewater outflow to the sewage treatment plant in particular months of 2011-2016

reason for the variation in the outflow of wastewater to the studied treatment plant was the level of precipitation (and in winter, precipitation trapped in the snow and released at the time of the thaw). In order to determine this impact in more detail, the study period was subdivided into groups of rainfall intensity in particular days.

\section{CONCLUSIONS AND ASSERTIONS}

The following conclusions and assertions can be formulated on the basis of the conducted research:

- For the studied multiyear period, the mean daily inflow of wastewater to the tested treatment plant was $13388.5 \mathrm{~m}^{3} \cdot \mathrm{d}^{-1}$, which accounted for $54.8 \%$ of the planned (designed) inflow. These values indicate that additional households can be connected to the sewage system.

- For the studied multiyear period (2011-2016), a high variability was observed in wastewater outflow from the analysed sewage agglomeration, in the range between $5302.0 \mathrm{~m}^{3} \cdot \mathrm{d}^{-1}$ and $40.630 .0 \mathrm{~m}^{3} \cdot \mathrm{d}^{-1}$ (i.e. the range of $35328.0 \mathrm{~m}^{3} \cdot \mathrm{d}^{-1}$ ). In most part, rainwater entering into the combined sewerage system, and foreign (external) water entering the sanitary (distribution) sewage system, are responsible for the maximum value. Large variations in wastewater outflow to the sewage treatment plant may pose a threat to the proper operation of the treatment plant, and lead to increased costs associated with sewage pumping.

- There is a clear correlation between the rainfall intensity group and wastewater outflow from sewage agglomerations. Considering that wastewater from the combined sewage system (which constitutes $40.6 \%$ of the total length) and from the distribution sewage system (which constitutes $59.4 \%$ of the total length) are outflowing from the studied facility, this suggests that the sewage system also receives foreign (external) water. The main reason for the inflow of foreign water to the analysed catchment, established on the basis of field studies and water smoke tests carried out by the water supply company, consisted in illegal connection of outlets from roof gutters or courtyard inlets to sewage sewers. Studies carried out in Germany (Karpf and Krebs 2005, Franz 2007) showed that between 18 and 56\% of foreign water in sanitary sewage is entering the sewers by means of leakages in the tops and manholes' openings. In Poland, similar research was conducted by Kaczor (2009), demonstrating that in the Małopolska region improper execution of sewer manholes can be an important reason for the penetration of rainwater into the sanitary sewage system.

- We should aim at moving from a combined sewage system to a distribution one. 
- In rainfall groups with higher intensity of atmospheric precipitation, higher values of the mean temperature of wastewater flowing into the treatment plant were observed. Such correlations result from the fact that groups without rainfall, especially those with a long dry season, fell during the winter period when the wastewater temperature was lower. High temperatures of wastewater flowing into the treatment plant were recorded in the period of the largest precipitation.

\section{REFERENCES}

Bergel, T., Pawełek, J. (2005). Struktura zużycia wody w gospodarstwach wiejskich. Ochrona środowiska, walory przyrodnicze i rozwój turystyki w dolinie Sanu materiały z II Konferencji Naukowo-Technicznej „Błękitny San", 165-173.

Bugajski, P., Chmielowski, K., Kaczor, G. (2016). Reliability of a Collective Wastewater Treatment Plant, In: Journal of Ecological Engineering (Inżynieria Ekologiczna), 17, 4, 143-147, DOI:10.12911/22998993/64505.

Bugajski, P., Chmielowski, K., Kaczor, G. (2016). Wpływ wielkości dopływu wód opadowych na skład ścieków surowych w małym systemie kanalizacyjnym, w: Acta Scientiarum Polonorum Formatio Circumiectus, 15, 2, 3-11, DOI:10.15576/ASP.FC/2016. 15.2.3

Bugajski, P., Ślizowski, R. (2006). Ocena działania oczyszczalni ścieków typu SBR w Sterkowcu-Zajazie. Infrastruktura i Ekologia Terenów Wiejskich. 2 (2).

Chmielowski, K., Bugajski, P., Kaczor, G. (2016). Compositional analysis of the sewage incoming to and discharged from the sewage treatment plant in Kolbuszowa Dolna, w: Journal of Ecological Engineering (Inżynieria Ekologiczna), 17, 5, 9-16, DOI: 10.12911/22998993/64446

Chotkowski, W., Lis, G. (2006). Krótkoterminowe prognozowanie odpływu ścieków do oczyszczalni na podstawie ilości zużywanej wody. Gaz, Woda i Technika Sanitarna 5, 13-18.

Dyrektywa (1991). Dyrektywa Rady z dnia 21 maja $1991 \mathrm{r}$. dotycząca oczyszczania ścieków komunalnych (91/271/ EWG).

Framz, T. (2007). Spatial classification methods for efficient infiltration measurments and transfer of measuring results. Disseration. Institut fur Siedlungs-und Industriewasserwirstschaft, TU Dresden. Dresdner Bericht, 28.

Kaczor, G. (2009). Otwory we włazach kanalizacyjnych jako jedna z przyczyn przedostawania się wód przypad- kowych do kanalizacji sanitarnej. Infrastruktura i Ekologia Terenów Wiejskich, 9, 155-163.

Kaczor, G. (2011). Wpływ wiosennych roztopów śniegu na dopływ wód przypadkowych do oczyszczalni ścieków bytowych. Acta Sci. Pol., Formatio Circumiectus, 2, 27-34.

Kaczor, G., Przebinda, A. (2009.) Analiza uszkodzeń kanałów sanitarnych po krótkim okresie eksploatacji. Inżynier Budownictwa, 11(67). Wydawnictwo Polskiej Izby Inżynierów Budownictwa sp. z o.o., 56-59.

Kaczor, G., Pawełek, J. (1999). Dobowe ilości ścieków w osiedlach wiejskich w aspekcie ich oczyszczania. Zeszyty Naukowe Akademii Rolniczej im. H. Kołłątaja w Krakowie, 350, 103-113.

Kaczor, G., Chmielowski, K., Bugajski, P. (2017). Wpływ sumy rocznej opadów atmosferycznych na objętość wód przypadkowych dopływających do kanalizacji sanitarnej, In: Annual Set The Environment Protection, Środkowo-Pomorskie Towarzystwo Naukowe Ochrony Środowiska, 19, 668-681.

Karpf, C., Krebs, P. (2005). Assessment of extraneus water inflow in separate sewer networks. Proceedings of the 10th ICUD Conference, Copenhagen, Denmark, 1-8.

Krajowy Program Oczyszczania Ścieków Komunalnych. (2003). Ministerstwo Środowiska. Warszawa.

Miernik, W., Młyński, D. (2014a). Analiza pracy oczyszczalni ścieków w Krzeszowicach po modernizacji. Episteme, 29, 303-310.

Miernik W., Młyński D. (2014b). Wpływ modernizacji oczyszczalni dla miasta Wadowice na jakość oczyszczonych ścieków. In: J. Rak (ed.): Antropogeniczne czynniki wpływu na środowisko przyrodnicze na przykładzie południowo-wschodniej Polski, wschodniej Słowacji i zachodniej Ukrainy, wyd. Muzeum Regionalnego im. Adama Fastnachta w Brzozowie, 109-129.

Młyński, D., Chmielowski, K. (2017). Analiza zmienności ilościowej ścieków dopływających do wybranych oczyszczalni powiatu sanockiego, In: Acta Scientiarum Polonorum Formatio Circumiectus, 16, 1, 70-99, DOI: http://dx.doi.org/10.15576/ASP.FC/2017.16.1.77

Rozporządzenie (2014a). Rozporządzenie Ministra Środowiska $\mathrm{z}$ dnia 18 listopada 2014 r. w sprawie warunków, jakie należy spełnić przy wprowadzaniu ścieków do wód lub do ziemi, oraz w sprawie substancji szczególnie szkodliwych dla środowiska wodnego. Dz.U. 2014 poz. 1800 .

Wąsik, E., Chmielowski, K., Operacz, A. (2017). PCA jako narzędzie eksploracji danych charakteryzujących pracę komór nitryfikacji oczyszczalni ścieków w Trepczy, w: Acta Scientiarum Polonorum Formatio Circumiectus, 16, 1, 209-222, DOI:10.15576 /ASP.FC/2017.16.1.209 


\section{WPŁYW OPADU ATMOSFERYCZNEGO NA ZMIENNOŚĆ ODPŁYWU ŚCIEKÓW Z WYBRANEJ AGLOMERACJI KANALIZACYJNEJ W JAWORZNIE}

\section{ABSTRAKT}

\section{Cel pracy}

Celem artykułu było określenie wpływu opadu atmosferycznego na zmienności odpływu ścieków z aglomeracji kanalizacyjnej w Jaworznie w Polsce południowej. Okres badań obejmował lata 2011-2016. Do analizy posłużono się dobowymi odpływami ścieków z aglomeracji kanalizacyjnej. Określono podstawowe statystyki opisowe ilości ścieków dopływających do zbiorczej oczyszczalni.

\section{Materiat i metody}

Pozyskano dane opadowe ze stacji oddalonej od o $7 \mathrm{~km}$ (najbliższa stacja opadowa od badanego obiektu) i na tej podstawie określono średnie wartości dobowego opadu atmosferycznego dla badanego okresu. Następnie dokonano podziału dób okresu badawczego ze względu na wielkość opadów atmosferycznych na 7 zasadniczych grup. Określono, czy średnie wartości odpływu ścieków z aglomeracji kanalizacyjnej w poszczególnych grupach intensywności opadowej w istotny sposób się od siebie różnią. Analiza ta została przeprowadzona z wykorzystaniem jednoczynnikowej analizy wariancji ANOVA. Czynnikiem determinującym wartość odpływu ścieków z aglomeracji kanalizacyjnej były grupy natężenia opadu deszczu.

\section{Wyniki i wnioski}

Na podstawie przeprowadzonych badań zaproponowano dla eksploatatora działania zwiększające kontrolę odpływu wód obcych do systemu kanalizacyjnego, a na tej podstawie działania minimalizujące dopływ wód obcych na odcinkach kanalizacji szczególnie wrażliwych. Należy wprowadzić szkolenia edukacyjne w gminie (aglomeracji) odnośnie zagospodarowania wód opadowych tak, aby zatrzymać je w jak największym stopniu w miejscu ich powstawania.

Słowa kluczowe: ścieki, opad atmosferyczny, oczyszczalnia ścieków, kanalizacja 